\title{
Culture of Silence, Professional Identity and the Educator: A State of the Question
}

\author{
Daniele Cariolano da Silva \\ Postgraduate Program in Education, State University of Ceará \\ Jacques Therrien \\ Postgraduate Program in Education, State University of Ceará
}

\begin{abstract}
This paper aims to establish an analytical framework about the culture of silence in the educator's identity, showing problems and theoretical and methodological bases. It is a cross-section of the research entitled Culture of Silence in the professional identity of Educational Topics Technicians and Educators in the light of the Freirean thought currently being carried out at the Postgraduate Program in Education (Academic Doctorate Degree in Education) of the State University of Ceará (PPGE/UECE). The methodology adopted at this stage was the qualitative research, resorting to the State of the Question, with a survey, review and deep bibliographical data analysis of the data, based on Freire's studies. Among other sources, the most important are the directories named Thesis and Dissertations Bank of the Coordinating Agency for Advanced Training of Graduate Personnel (CAPES), the Brazilian Digital Library of Thesis and Dissertations (BDTD), and the CAPES Journals Portal. The results include 36 mapped papers, 10 of which deal with the culture of silence, and 26 of which deal with the educator's professional identity. We verified a predominance of the qualitative approach of investigation, with a quantitative highlight for bibliographical, documentary, and field/exploratory research. Among the data collection procedures, the application of a questionnaire and the conduction of a semi-structured interview stand out. As for the theoretical bases, the studies by Paulo Freire and Venício Artur Lima ('Culture of silence' category); Stuart Hall and Claude Dubar ('Identity' category); and Selma Garrido Pimenta, José Carlos Libâneo and Dermeval Saviani ('Educator' category). Thus, considering the theoretical and methodological contributions (investigative purpose, goals, problems, analysis categories and references), we emphasize the pertinence of more and deeper reflections about the State of the Question as an original, creative, critical and contributory manner in comparison with scientific research.
\end{abstract}

Keywords: State of the Question. Academic papers. Theoretical and methodological bases

DOI: $10.7176 /$ RHSS/10-16-01

Publication date:August $31^{\text {st }} 2020$

\section{Introduction}

This paper aims to establish an analytical framework of studies about the culture of silence in the educator's identity, bringing up problems and theoretical and methodological bases. It is a cross-section from the research entitled Culture of Silence in the professional identity of Educational Topics Technicians and Educators in the light of the Freirean thought currently being carried out at the Postgraduate Program in Education (Academic Doctorate Degree in Education) of the State University of Ceará (PPGE/UECE).

There is the problem in which the culture of silence in dominated consciousnesses is supported by immobilizations, weaknesses, dualities, and by the fatalistic mythification of reality, fostering and maintaining human consciousness of semi-intransitivity. In neoliberal times, the fatalisms and naturalization of silence seem to gain power and substance in educational institutions, since "the fatalist, immobilizing ideology that stirs the neoliberal discourse is on the loose the world over. With an air of post-modernism, it insists on convincing us that there is nothing we can do against social reality, which, from historical and cultural, becomes or turns into almost natural" (FREIRE, 1996, p. 19). It is based on monotonous and repetitive discourses about a fixed, immutable, naturalized reality; there is nothing we can do to change it.

Within this context, social, educational and formative institutions, such as family households, schools and universities, located in their time and space, "[...] cannot escape the influences of structural objective conditions. They work, to a great extent, within dominating structures such as agencies preparing future invasions" (FREIRE, 2019 , p. 208), among which are the cultural structure and its processes of incorporation, passive acceptability, defense, and reproducibility. Such sociohistorical, economic, political and cultural conjuncture tends to influence and reproduce itself in educational institutions by means of introjecting myths based on a supposed verticalized authority and the erroneous convictions of people's absolute unculture, incapacity, inferiority, and ignorance.

Faced with the problematic outlook that intertwines society, the culture of silence, educational institutions and their agents, concerns arise with specific features about education professionals, about the recent scientific scenario surrounding the topic: What is the current analytic context of scientific studies related to the "culture of silence - professional identity - educator" triad? Which problems and theoretical and methodological 
assumptions? What is the current State of the Question?

We start from the understanding that, based on a bibliographical survey, the State of the Question (SQ) allows us to see what the situation of the object of the investigation is in academic papers produced so far (the scientific findings), generating a much broader outlook around the problem and its theoretical and methodological bases, thus promoting some understandings, connections, and registration of questions, contexts and biases directly linked to the research topic. Thus, we promote scientific rigor, creativity, criticism; moreover, a reflective, argumentative, sensitive, and intuitive attitude is also expected from the researcher in his/her choices and investigative delimitations.

The State of the Question manifests itself beyond the identification of theories, concepts and categories delineated in scientific papers, since it subsidizes the whole research project in the (re)definition and planning of objectives, in the theoretical and methodological field necessary to date analysis and interpretation, in discussions, arguments and contributions - whether partial or not - to the construction of knowledge. Therefore, it contributes towards reaching the research topic, unveiling its specific features by offering a glimpse of what already exists in current science, and of what is new in the proposed study.

There is the possibility of a macro approach of how a given knowledge area is, and of specifying it based on the bibliographical review (ALVES-MAZZOTI, 1998) pertaining to the research problem, which broadens the analysis of previous investigations (already carried out) on the topic, and is present in theoretical discussions. Such procedure aims to identify the impact, relationships, and proximity of some studies to the problem, the investigation object, the proposed objectives, the theoretical and methodological questions, the categories, and constructs relevant to the research.

The premise is that the study on the State of the Question, however, is not limited to the descriptive and enumerating act of the state of the art, nor to reviewing theories, as it [...] somehow transcend the limits of a literature review focused exclusively in the explanation of theories, concepts and categories" (NÓBREGA THERRIEN; THERRIEN, 2004, p. 11). It allows more than diving into the literature, as it helps to identify indispensable theoretical and methodological elements, to delimit specific features of the object under investigation and, as a result, of questions and categories. At last, it makes the researcher's final, rigorous, creative, and original production possible.

For that purpose, in view of the foregoing, we initially resorted to carrying out a qualitative research, and a study of the State of the Question, with a survey, review and deep bibliographical analysis of the data from Freire's studies.

\section{Theoretical and methodological route}

The State of the Question means a selective bibliographical research, search in sources such as dissertations, theses, and research reports, clarity and delimitation of originality and collaboration, making up "[...] the clarification about the researcher's position and his/her study object in the preparation of a narrative text, his/her concept of science, and the epistemic contribution thereof to the field of knowledge" (NÓBREGA-THERRIEN; THERRIEN, 2010, p. 37-38), i.e., it expresses in the researcher's own argumentative form his/her perception on what has so far been produced and is now analyzed by him/her, as well as the path to be treaded and where he/she wants to arrive.

In this path and considering the topic "culture of silence in the educator's professional identity", this State of the Question attempted to bring up the main academic papers written on the topic, which allowed an initial approximation and further analyses, reflections, and a deeper theoretical insight about the study object, redefinition of objectives and delimitation of theoretical categories, among other purposes. Such mapping, by means of electronic repositories, took into account the following descriptors: culture of silence, professional identity, and educator. Despite the choice for the theoretical "Pedagogy" category, during our process of looking for studies, we chose to use the "Educator" descriptor, singling it out from other writings that encompass other aspects and dimensions of such complexity typical of the Education science.

The search through the data platforms was carried out based on: I - the "culture of silence" descriptor, between quotation marks and separately, since no paper was found when we associated this descriptor to another one; and II - the "professional identity" AND "educator" descriptors, between quotation marks and joined together by a Boolean AND, since such descriptors, when used separately, cover countless papers that do not meet the criteria established for this study.

We resorted to surveying theses and dissertations published in the Theses and Dissertations Catalog of the Coordinating Agency for Advanced Training of Graduate Personnel (CAPES) and in the Brazilian Digital Library of Theses and Dissertations (BDTD). The choice for the aforementioned databases is due to the wide coverage of knowledge, broad and free access, credibility and rigor required for the insertion and publication of papers in partnership with Brazilian educational and research institutions, making up digital systems renowned for the publicization and consolidation of the scientific and cultural heritage.

As for the choice for papers at the Master's or Doctoral level, this is justified by the scientific, theoretical 
and methodological rigor of the research already finished and published, which allows us to understand its entirety, complexity, the challenges and possibilities intertwined throughout its investigative development, a process which maybe was not feasible if we had look for essays in journals, due to their structural and coverage limitations, which sometimes turned them into mere cross-sections or succinct research texts.

Afterwards, however, the necessity arose to also carry out a survey through scientific journals, given the upto-date nature of the papers, and the low number of theses and dissertations found containing the 'culture of silence' descriptor, which made it necessary to expand the search into academic journals. Thus, the initial study survey also considered the journals portal of the Coordinating Agency for Advanced Training of Graduate Personnel (CAPES)

There is temporal cross-section covering the period from 2009 to 2018, for considering Law No. 11.892, of 29 December 2008 which established the Federal Network of Professional, Scientific and Technological Education (RFEPCT), as well as the Federal Institutes of Education, Science and Technology (10 years). Such temporal delimitation is justified by the fact that the broader research still being carried out had its locus at the Federal Institute of Education, Science and Technology (IFCE).

The papers were also selected according to the following criteria: I - availability of digital material for public searches; II - occurrence in the knowledge area of Humanities/Education; III - connection (it does not need to be the program's concentration area) with teacher training; IV - based on the 'culture of silence', 'professional identity' and 'educator' descriptors; and V - proximity with the topic and problems dealt with under this research.

The information collected was organized into tables that initially classified the data according to the repository looked at, descriptors used, initial results after filters and refinements, as well as final results after a preliminary analysis. Subsequently, at another stage of the analysis, the focus was shifted to the theoretical and methodological references adopted in the mapped papers, specifically in regard to the methodology and theoretical framework adopted, with explanations of information about the types of research, data collection procedures, and reference authors.

In sum, the following stages of the SQ were delimited: I - survey into the data bases for descriptors separately (only used with quotation marks). Next, the search was made with descriptor combinations (Boolean) and, finally, using filters and refinements (inclusion and exclusion aspects); II - preliminary analysis, including reading the title, abstract and keywords, which also resulted in exclusions and inclusions for the following stage. At this stage, the tables showed the research papers chosen with the purpose of analyzing, in an introductory manner, investigation problems (questions), objectives, research participants, central study topics based on descriptors, keywords or analysis categories, , theoretical assumptions, methodologies used, and results achieved. Such process took place in the beginning and based on reading the papers' title, abstract, and keywords; and III thorough analysis of the final material (thesis, dissertation or article), with an emphasis in their theoretical and methodological aspects (methodology and theoretical framework), in an attempt to clarify such references.

Therefore, in order to prepare her own narrative, the researcher had to "see herself stuck in front of computer, pencil on paper, a pause for reflection, the question as to what the starting point and final destination are” (NÓBREGA-THERRIEN; THERRIEN, 2010, p. 40) and, at last, starts writing the text.

\section{State of the question - sq: surveys, refinements and analyses}

We initially surveyed the papers in the Theses and Dissertations Database of the Coordinating Agency for Advanced Training of Graduate Personnel, in the Brazilian Digital Library of Theses and Dissertations (BDTD) and in the Journals Portal of the Coordinating Agency for Advanced Training of Graduate Personnel (CAPES). As for the search for theses and dissertations, the mapping started based on the "culture of silence", "professional identity", and "educator" descriptors, first entered separately and then in combinations (use of AND) and filtered with quotations marks ("'). Afterwards, the search was carried out with these descriptors, keeping the quotations marks along with refinements (document type, year of defense, language, broader knowledge area, and knowledge area).

Then, a preliminary analysis was carried out of the document (title, abstract and keywords), and it was decided whether each paper would be removed or remain into the second stage of the analysis. Thus, we managed to obtain the initial findings, then the results after filtering and refinements and, lastly, the final count after the preliminary analysis. As for the search in the Journals Portal of the Coordinating Agency for Advanced Training of Graduate Personnel (CAPES), a survey was carried out with the initial findings but, as the amount of papers found was low, we decided not to refine the search, since we aimed to increase the possibility of finding texts which were relevant to the SQ study. Thus, all initial results went through a preliminary analysis. 


\subsection{Theses and Dissertations Database of the Coordinating Agency for Advanced Training of Graduate Personnel (CAPES) 1}

This is a Catalog of Theses and Dissertations of the Coordinating Agency for Advanced Training of Graduate Personnel (CAPES), a kind of bibliographical search system that digitally gathers abstracts of theses and dissertations produced in the accredited Master's and Doctorate Programs. This database can be accessed by the whole scientific community without need of registration, since it only requires the user to indicate/type what he/she wants to find in the search field. It is worth noting that the use of the database information and records is subjected to the copyright laws in effect.

As for the search procedures, there is a panel with quantitative information and the option to refine results by type, year, author, advisor, examining board, broader knowledge area, knowledge areas, evaluation and concentration, program title, institution, and library. In order to obtain the full text of the papers (theses and dissertations), the portal forwards the user to the Sucupira Platform. It is worth noting, however, that not all papers are available, as it is necessary to have access to the papers via the website of the original library or another possible route. The following mapping was obtained for this study:

Table 1 - Mapping in the Theses and Dissertations Catalog of the Coordinating Agency for Advanced Training of Graduate Personnel (CAPES)

\begin{tabular}{l|l|l|l|l}
\hline \multicolumn{5}{c}{ MAPPING IN THE CAPES THESES AND DISSERTATIONS CATALOG } \\
\hline & $\begin{array}{l}\text { INITIAL } \\
\text { RESULT } \\
\text { S }\end{array}$ & $\begin{array}{l}\text { RESULTS } \\
\text { AFTER } \\
\text { FILTERS/REFI } \\
\text { NEMENTS }\end{array}$ & $\begin{array}{l}\text { FINAL RESEARCH } \\
\text { FINDINGS } \\
\text { (after preliminary } \\
\text { analysis) }\end{array}$ & $\begin{array}{l}\text { PERCENTAG } \\
\text { E (\%) } \\
\text { * of final } \\
\text { findings in } \\
\text { relation to } \\
\text { initial results }\end{array}$ \\
\hline $\begin{array}{l}\text { "CULTURE OF SILENCE" } \\
\text { "CULTURE OF SILENCE" AND } \\
\text { "PROFESSIONAL IDENTITY" }\end{array}$ & 27 & 3 & 2 & $7.40 \%$ \\
\hline $\begin{array}{l}\text { "CULTURE OF SILENCE" AND } \\
\text { "EDUCATOR" }\end{array}$ & 0 & 0 & 0 & $0.00 \%$ \\
\hline $\begin{array}{l}\text { "PROFESSIONAL IDENTITY" } \\
\text { AND "EDUCATOR" }\end{array}$ & 42 & 19 & 0 & $0.00 \%$ \\
\hline SUBTOTAL & 69 & 22 & 14 & $33.33 \%$ \\
\hline $\begin{array}{l}\text { REPEATED OR } \\
\text { UNAVAILABLE/UNIDENTIFIE } \\
\text { D PAPERS }\end{array}$ & - & - & $\begin{array}{l}2 \\
\text { (access only to title, } \\
\text { abstract and keywords })\end{array}$ & 16 \\
\hline TOTAL & 69 & 22 & 14 & $23.18 \%$ \\
\hline
\end{tabular}

Source: Prepared by the author of the study.

Out of $69(100 \%)$ mapped papers, $27(39.13 \%)$ were related to the "culture of silence" descriptor, and 42 $(60.86 \%)$ to the association of the phrases "professional identity" and "educator". After this refinement and filtering stage (year: 2009 through 2018; type: academic theses and dissertations; broader knowledge area: humanities; knowledge area: education; language: Portuguese), out of these 69 papers, 22 studies remained, since, from a total of $27(100 \%)$ papers around the "culture of silence" descriptor, only $3(11.11 \%)$ were chosen, and, from a total of $42(100 \%)$ papers found about "professional identity" AND "educator", 19 were chosen $(45.23 \%)$. No paper was found for the descriptor combinations "culture of silence" AND "professional identity", and "culture of silence" AND "educator".

Despite the reasonable number of papers found in total, after the refinement and filtering stage, out of the 69 documents initially surveyed, only 22 remained. After the preliminary analysis (reading of the title, abstract and keywords), out of these 22 papers, only 16 remained to the following stage, 2 of which were found for the "culture of silence" descriptor, 14 for the descriptor combination "professional identity" (Boolean) AND "educator" and 6 were discarded for not meeting the criteria required for the study on the state of the question.

In percentage terms, out of $16(100 \%)$ final papers found in the CAPES platform, $87.50 \%$ (14) were about the educator's identity, and only $12.50 \%$ (2) are related to the "culture of silence" topic, which demonstrates a field that is yet to be unveiled within the education sphere. It is worth stating that, out of the 16 preliminarily analyzed final papers, 2 of them ("The route of professional educators' training from 1960 to 2006: reflecting on the ANFOPE documents and the field of pedagogy, of 2009, written by Ericka Ferreira da Cunha; and The constitution of Pedagogy students' teaching identity: from teacher to manager, of 2012, written by Elizangela Fernandes Martins) were excluded and did not pass into the deeper analysis stage, since their full texts were not found, which resulted in a final total of 14 papers selected.

\footnotetext{
${ }^{1}$ Information available at: https://catalogodeteses.capes.gov.br. Accessed on September 06, 2019.
} 
In sum, between the initial number of papers (69) and the remaining total after the refinement stage (22), 47 papers were excluded, which is due to the application of filters necessary to greater accuracy and connection between the survey and the SQ purpose intended herein. Regarding the total after filters (22) and the final total after the initial analysis of the papers (14), 8 papers were excluded: 2 due to the lack of access to the full text, and 6 due other reasons.

\subsection{Digital Brazilian Library of Theses and Dissertations (BDTD) ${ }^{2}$}

The platform is part of a kind of network concentrated into only one portal, which, in its turn, concentrated all databases connected to the postgraduate programs of accredited Higher Education institutions, comprising a national system of information on theses and dissertations in Brazil. It contributes towards time optimization, due to the organization of electronic addresses within only one digital place where one can access these documents. For this purpose, the Brazilian Institute of Information on Science and Technology (IBICT) collects and makes metadata available (title, author, abstract, keywords) from the papers, whose full texts remain at the institution where it was defended, and a direct access link is made available to users, so that they can go into a virtual space where the original document can be accessed. The following papers were extracted from this material:

Table 2 - Mapping in the Digital Brazilian Library of Theses and Dissertations (BDTD)

\begin{tabular}{|c|c|c|c|c|}
\hline \multicolumn{5}{|c|}{$B D T D$ MAPPING } \\
\hline DESCRIPTORS & $\begin{array}{l}\text { INITIAL } \\
\text { RESULTS }\end{array}$ & $\begin{array}{c}\text { RESULTS AFTER } \\
\text { FILTERS/REFINEMENTS }\end{array}$ & $\begin{array}{c}\text { FINAL } \\
\text { RESEARCH } \\
\text { FINDINGS } \\
\text { (after preliminary } \\
\text { analysis) }\end{array}$ & $\begin{array}{l}\text { PERCENTAGE } \\
(\%) \\
\text { *of final findings } \\
\text { in relation to } \\
\text { initial results }\end{array}$ \\
\hline $\begin{array}{l}\text { "CULTURE OF } \\
\text { SILENCE" }\end{array}$ & 16 & 1 & 1 & $6,25 \%$ \\
\hline $\begin{array}{l}\text { "CULTURE OF } \\
\text { SILENCE" AND } \\
\text { "PROFESSIONAL } \\
\text { IDENTITY" }\end{array}$ & 0 & 0 & 0 & $0,00 \%$ \\
\hline $\begin{array}{l}\text { "CULTURE OF } \\
\text { SILENCE" AND } \\
\text { "EDUCATOR" }\end{array}$ & 0 & 0 & 0 & $0,00 \%$ \\
\hline $\begin{array}{l}\text { "PROFESSIONAL } \\
\text { IDENTITY" AND } \\
\text { "EDUCATOR" }\end{array}$ & 288 & 24 & 7 & $2,43 \%$ \\
\hline SUBTOTAL & 304 & 25 & 8 & $2,63 \%$ \\
\hline $\begin{array}{c}\text { REPEATED OR } \\
\text { UNAVAILABLE/UNID } \\
\text { ENTIFIED PAPERS }\end{array}$ & - & - & - & \\
\hline TOTAL & 304 & 25 & 8 & $2,63 \%$ \\
\hline
\end{tabular}

Source: Prepared by the author of the study.

From the table above, we can verify that 304 (100\%) documents were mapped, $288(94.73 \%)$ of which were identified with the association of the "professional identity" AND "educator" descriptors, and 16 (5.26\%) with the "culture of silence" descriptor. Similarly to what happened during the search at the CAPES theses and dissertations platform, there was a greater number of papers related to the educator's identity when compared to the findings on culture of silence, a topic that seems to be little discussed in Education, but seen with closer attention in the field of Communication/Languages/Journalism.

At the end of the refinement and filtering stage (year: 2009 through 2018; type: academic theses and dissertations; broader knowledge area: humanities; knowledge area: education; language: Portuguese), out of 304 (100\%) papers, only $25(8.22 \%)$ documents remained, since, from a total of $288(100 \%)$ papers around the "professional identity" AND "educator" descriptors, only $24(8.33 \%)$ were chosen, and, from a total of $16(100 \%)$ papers found about "culture of silence", only 1 was chosen $(6.25 \%)$. No paper was found for the descriptor combinations "culture of silence" AND "professional identity", and "culture of silence" AND "educator".

In sum, after the refinement and filtering stage, out of the 304 documents initially surveyed, only 25 remained. After the preliminary analysis (reading of the title, abstract and keywords), out of these 25 papers, only 8 remained to the following stage: 1 for the "culture of silence" descriptor and 7 for the descriptor combination "professional identity" (Boolean) AND "educator". Represented as percentages, out of the 8 (100\%)

\footnotetext{
${ }^{2}$ Information available at: http://bdtd.ibict.br/vufind. Accessed on July 17, 2019.
} 
final papers found at the BDTD database, $87.50 \%$ (7) dealt with the educator's identity, and only $12.50 \%$ (1) was about the culture of silence, which justifies even more the importance of carrying out research on the this and other topics connected to the educational area.

In sum, between the initial number of papers (304) and the remaining amount of 25 after the refinement stage, 279 papers were excluded, which is due to the application of filters necessary to connect the SQ purpose and the thesis being developed herein. Regarding the total after filters (25) and the final total after the initial analysis of the papers (8), we can see that 17 papers were excluded.

\subsection{Journals Portal of the Coordinating Agency for Advanced Training of Graduate Personnel $(C A P E S)^{3}$}

Considering the Brazilian libraries' lack of access to international scientific information and the different regional levels when it comes to access this information in Brazil, the Journals Portal was officially launched in 2000, and is completely funded by the Brazilian government. The Coordinating Agency for Advanced Training of Graduate Personnel (CAPES) then start centralizing and optimizing the acquisition of this type of content by negotiation directly with international editors.

It is a virtual library that gathers and makes scientific papers available to educational and research institutions in Brazil. It features full texts, references, exclusively patent-dedicated databases, as well as books, encyclopedias and reference works, technical standards, statistics, and audiovisual content. The establishment of the portal thus aims to satisfy the demands of the academic, production and governmental sectors, increasing the domestic scientific production and the Brazilian scientific insertion abroad.

Because of the free access granted to teachers, researchers, students and employees of the participating institutions, the platform promotes the strengthening of postgraduate programs in Brazil through the democratization of online access to international, high-quality scientific information. Search in the portal can be performed by topic, journal, book or database, either in a simple or advanced search, in which filters and refinements can be inserted (language, collection, author, date of publication, type of resource, among others).

Table 3 - Mapping of the Journals Portal of the Coordinating Agency for Advanced Training of Graduate Personnel (CAPES)

\begin{tabular}{|c|c|c|c|c|}
\hline \multicolumn{5}{|c|}{ MAPPING OF THE CAPES JOURNALS PORTAL } \\
\hline DESCRIPTORS & $\begin{array}{l}\text { INITIAL } \\
\text { RESULTS }\end{array}$ & $\begin{array}{c}\text { RESULTS AFTER } \\
\text { FILTERS/REFINEMENTS }\end{array}$ & $\begin{array}{c}\text { FINAL } \\
\text { RESEARCH } \\
\text { FINDINGS } \\
\text { (after preliminary } \\
\text { analysis) }\end{array}$ & $\begin{array}{l}\text { \% } \\
\text { (of the final } \\
\text { findings in } \\
\text { relation to } \\
\text { the initial } \\
\text { ones) }\end{array}$ \\
\hline "CULTURE OF SILENCE” & 18 & $\begin{array}{l}\qquad 18 \\
\text { Note: there were no filters or } \\
\text { refinements }\end{array}$ & 7 & $38,88 \%$ \\
\hline $\begin{array}{c}\text { "CULTURE OF SILENCE" } \\
\text { AND "PROFESSIONAL } \\
\text { IDENTITY" }\end{array}$ & 0 & 0 & 0 & $0,00 \%$ \\
\hline $\begin{array}{l}\text { "CULTURE OF SILENCE" } \\
\text { AND "EDUCATOR" }\end{array}$ & 0 & 0 & 0 & $0,00 \%$ \\
\hline $\begin{array}{l}\text { "PROFESSIONAL } \\
\text { IDENTITY" AND } \\
\text { "EDUCATOR" }\end{array}$ & 21 & $\begin{array}{l}\text { Note: there were no filters or } \\
\text { refinements }\end{array}$ & 7 & $38,88 \%$ \\
\hline SUBTOTAL & 39 & 39 & 14 & $35,89 \%$ \\
\hline $\begin{array}{c}\text { REPEATED OR } \\
\text { UNAVAILABLE/UNIDEN } \\
\text { TIFIED PAPERS }\end{array}$ & - & - & & \\
\hline TOTAL & 39 & 39 & 14 & $35,89 \%$ \\
\hline
\end{tabular}

Source: Prepared by the author of the study.

Out of $39(100 \%)$ mapped papers, $18(46.15 \%)$ were related to the "culture of silence" descriptor, and 21 $(53.84 \%)$ to the association of the phrases "professional identity" and "educator". Given the low amount of papers initially surveyed, we chose not to perform a more specific search narrowed down by the use of filters and refinements, so as to avoid the risk of letting some paper which could be important to the State of the Question go unnoticed. Thus, immediately after the initial findings, all of them went through the preliminary analysis, which resulted in texts being either removed or maintained for the later analysis stage.

In sum, out of the 39 documents initially surveyed, all of them were analyzed in a preliminary manner

\footnotetext{
${ }^{3}$ Information available at: http://www.periodicos.capes.gov.br/ . Accessed on October 14, 2019.
} 
(reading of the title, abstract and keywords), 14 of which remained -7 for the "culture of silence" descriptor, and 7 for the descriptor combination "professional identity" (Boolean) AND "educator". Out of the 39 papers, 14 remained, since out of the $18(100 \%)$ studies about the "culture of silence" descriptor, only $7(38.88 \%)$ were chosen, and, out of the $21(100 \%)$ of studies related to the "professional identity" AND "educator" descriptors, only $7(33.33 \%)$ were chosen as well. No paper was found for the descriptor combinations "culture of silence" AND "professional identity", and "culture of silence" AND "educator".

In percentage terms, out of the $14(100 \%)$ final papers found in the Journals Portal of the Coordinating Agency for Advanced Training of Graduate Personnel (CAPES), 50\% (7) dealt with the educator's identity, and $50 \%$ (7) dealt with the "culture of silence" topic, which demonstrates that the topic has somehow come up in discussions and deeper analysis within the scope of scientific journals. In sum, between the initial total of 39 papers and the total after the preliminary analysis (14), 25 papers were removed, for various reasons.

\subsection{Analysis of the theoretical methodological bases}

Below is a table with the final data mapped in the three repositories chosen (the CAPES Theses and Dissertations Catalog, Digital Brazilian Library of Theses and Dissertations, and the CAPES Journals Platform) covering the three types of documents required (theses, dissertations and articles).

Table 4 - Total Mapping (all three repositories)

\begin{tabular}{|c|c|c|c|c|}
\hline \multicolumn{5}{|c|}{ TOTAL MAPPING } \\
\hline DESCRIPTORS & $\begin{array}{c}\text { CAPES THESES AND } \\
\text { DISSERTATIONS } \\
\text { CATALOG }\end{array}$ & $\begin{array}{l}\text { DIGITAL BRAZILIAN } \\
\text { LIBRARY OF THESES } \\
\text { AND DISSERTATIONS } \\
\text { (BDTD) }\end{array}$ & $\begin{array}{c}\text { CAPES } \\
\text { JOURNALS }\end{array}$ & TOTAL \\
\hline $\begin{array}{l}\text { "CULTURE OF } \\
\text { SILENCE" }\end{array}$ & 2 & 1 & 7 & 10 \\
\hline $\begin{array}{l}\text { "CULTURE OF } \\
\text { SILENCE" AND } \\
\text { "PROFESSIONAL } \\
\text { IDENTITY" }\end{array}$ & 0 & 0 & 0 & 0 \\
\hline $\begin{array}{l}\text { "CULTURE OF } \\
\text { SILENCE" AND } \\
\text { "EDUCATOR" }\end{array}$ & 0 & 0 & 0 & 0 \\
\hline \multirow[t]{2}{*}{$\begin{array}{l}\text { "PROFESSIONAL } \\
\text { IDENTITY" AND } \\
\text { "EDUCATOR" }\end{array}$} & 12 & 7 & 7 & 26 \\
\hline & Total: 14 & Total: 8 & Total: 14 & 36 \\
\hline
\end{tabular}

\section{Source: Prepared by the author of the study.}

At the end of the first stage (preliminary analysis), it was verified that, 36 papers were mapped altogether (10 on the culture of silence, and 26 on the educator's professional identity), distributed as follows: I - from the CAPES Theses and Dissertations Catalog, 14 papers were chosen ( 2 for the "culture of silence" descriptor, and 14 for the Boolean combination "professional identity" and "educator"); II - from the Brazilian Library of Theses and Dissertations, 8 papers were chosen ( 1 on the culture of silence, and 7 on the educator's identity). In this repository, there were fewer final findings; and III - from the CAPES Journals Platform, 14 papers were chosen ( 7 for the "culture of silence" descriptor, and 7 for the "professional identity"-"educator" combination).

In sum, only 10 papers on the culture of silence were mapped in the three data repositories chosen, which reveals the scarcity of studies on the topic, especially when it comes to dissertations and theses, which require deeper theoretical support. Such fact confirms the need of deep discussions about the society that restrains voices, words and the human expression, where communication and dialogue are denied, and shows marks of silencing the oppressed masses, since "in these sad neoliberal times, when we try to substitute popular sovereignty for 'market' sovereignty, a good example of the reach of the Freirean thought is the analytical potential of the culture of silence concept and its corollary — silencing policies" (LIMA, 2018, p. 2).

For this stage, a thorough analysis was carried out of the final material (36 works, among theses, dissertations and articles), with an emphasis in their theoretical and methodological aspects (methodology and theoretical framework), so as to elucidate the references and concepts to be used in the broader research. Thus, the boxes show data on the types of research, possible methods described, data collection procedures, and the main reference authors for the "culture of silence", "identity" and "pedagogy" categories.

Within the scope of methodology, specifically of the types of research and methods adopted in the papers being analyzed, it was possible to verify: I - qualitative research (life history/oral life history), used in 4 papers; II - bibliographical research, in 10 papers; III - documentary research, carried out in 7 papers; IV - field 
research, in 5 papers; V - qualitative research (Theory of Social Representations), in 3 papers; VI - biographical research, in 2 papers; VII - exploratory research (case study), carried out in 3 papers; VIII - quali-quantitative research (Theory of Social Representations), used in only 1 paper; IX - qualitative research (theme-based investigation), in 2 papers; $X$ - qualitative research (no description of the method), shown in 5 papers; and XI exploratory research (no description of the method), in 1 paper mapped.

The use stands out of a qualitative investigation approach, in which the natural environment is considered the main data source, making the researcher need a direct and lengthy contact with the milieu and the situation under investigation; emphasis is given to the investigation process (to the time, space, subjects and relationships comprising the complexity of daily life) in comparison with the research product; and, in order to portray the subjects' perspectives, many of the situations investigated have their relevance, which justifies the fact that the data obtained are diverse and predominantly descriptive (BOGDAN; BIKLEN, 2006). Thus, it is possible to visualize the several dimensions of the phenomenon, the factors that generate a clearer, deeper, processual, descriptive understanding.

Regarding the qualitative investigation assumptions, a greater predominance was shown of bibliographical, documentary, and field research. In many of these papers, however, the methods adopted were not described. Only a few papers contained explanations about the use of the theory of social representations, of life history, and study case as methods or methodologies. There is also a recurrence of frailties regarding the understanding and use of types of research, methods and instruments for data collection. While some papers were found that had no reference to the research method, in other papers, three types of research were mentioned in a single scientific investigation. It is worth noting that the terms/concepts/categories approached here were taken, as faithfully as possible, from the mapped papers.

As for the use of procedures, strategies and data collection instruments in the mapped papers, the findings were the following: I - written memorandum/autobiographical narratives (2 papers); II - autobiographical interview (1 paper); III - documentary analysis/documentary review (13 papers); IV - semi-directive interview (1 paper); V - bibliographical review (5 papers); VI - interviews (per theme-based cycles/topics/subjects), mentioned in 4 papers; VII - questionnaires (11 papers); VIII - biographical interviews (1 paper); IX - focus group (2 papers); X - observation (3 papers); XI - interviews (oral histories/narratives), in 1 paper; XII research meta-analysis (1 paper); and XIII - semi-structured interviews (14 papers).

The high number of papers stand out that resorted to bibliographical reviews and documentary review, which reveals a relationship with the notoriety of the bibliographical and documentary investigations explained above. The application of questionnaires was quantitatively high, and the semi-structured interview, in first place, was the main instrument chosen in the research mapped papers, to the detriment of other strategies. Maybe that choice was due to the fact that, according to Ludke and André (1986) this technique allows "the immediate and current capture of the information wanted, with pretty much any kind of informant and about the most diverse topics. A well-conducted interview can allow us to deal with strictly personal and intimate subjects [...]”, as well as with more complex topics. Interviews allow corrections, clarifications, and adaptations over their course.

Some frailties were equally noticed regarding the understanding and use of these different strategies, apart from some incongruences and reductionisms related to the bibliographical research/bibliographical review, documentary research/documentary review, and documentary research/documentary analysis binomials. We found both papers that mentioned only the use of documentary analysis, without stating types or assumptions, as well as papers that used three types of data collection strategies in the same scientific investigation. The terms/concepts/categories reported herein were taken from the mapped papers.

As for the theoretical references used to substantiate the papers, the findings were as follows, according to each theoretical category adopted herein:"Culture of silence" category: I - Paulo Freire, referred to in 7 papers (2 theses, 5 articles), through several of his works; II - Venício Artur Lima, referred to in 3 papers (2 theses, 1 article); III - João Brant and Diogo Moysés, authors of a work referred to in 1 paper (1 thesis); IV - Mikhail Bakhtin, referred to in 1 paper (1 thesis); V - Helena Hathsue Nagamine Brandão, one work used in the theoretical framework of 1 paper (1 thesis); VI - Pierre Bourdieu, an author referred to in 1 paper (1 thesis); VII Ernani Maria Fiori, whose studies were used in 2 of the mapped papers (1 thesis, 1 article); VIII - Jesús Martín Barbero, referred to in 1 paper (1 thesis); IX - F. G. D. Vieira, J. M. Crubellate, I. G. Silva and W. R. Silva, authors of 1 work used in 1 paper $(1$ article); X - P. Sloterdijk, referred to in 1 article; XI - D. Auler and D. Delizoicov, authors referred to in 1 paper (1 article); XII - M. Buber, in 1 article; XIII - J. C. da Mota Neto, in 1 scientific article; XIV - F. Fanon, whose studies were referred to in 1 article; XV - Danilo R. Streck, with a work referred to in 1 article; and XVI - O. Vieira, referred to in 1 article.

Regarding the discussions on the culture of silence, within the theoretical framework of these papers, works stand out by Paulo Freire, whose works were referred to in 7 papers, as well as by Venício Artur Lima, which was fundamental in 3 papers. Such investigations bring to light some reflections about the statement that "the culture of silence, finally, characterizes the society to which communication and dialogue are denied, and, instead of them, offers "communiqués", it is worth noting, is the environment of voice-silencing and absence of 
communication, of incommunicability (LIMA, 2011, p. 4), with "muteness" marks and multiple forms of human silencing in several social space-times.

"Identity" category: I - Stuart Hall, with several works referred to in 6 papers (6 theses); II - Antonio da Costa Ciampa, referred to in 5 theses; III - Claude Dubar, also with several studies referred to in 8 mapped papers ( 7 theses and 1 article); IV - Tomaz Tadeu da Silva, used as theoretical basis in 3 papers ( 2 theses and 1 article); V - Kathyn Woodward, referred to in 2 theses; and VI - Zygmunt Bauman, referred to in the theoretical framework of 2 theses. There is a greater recurrence of studies by Stuart Hall (referred to in 6 papers) and Claude Dubar (referred to in 8 mapped papers) in the theoretical frameworks of papers discussing identity and difference within the sphere of post-modernism (HALL, 2004), and the relationship between identity, socialization, and professional identity models (DUBAR, 2005).

"Pedagogy" category: I - M. A. da S. Aguiar, referred to in 6 papers (5 theses, 1 article); II - Selma Garrido Pimenta, with several works used in 16 papers (13 theses, 3 articles); III - Iria Brzezinski, with several studies referred to in 14 papers (10 theses, 4 articles); IV - M. A. S. Franco, referred to in 8 papers ( 7 theses, 1 article); V - C. Gauthier, referred to in 2 theses; VI - José Carlos Libâneo, with different works referred to in 20 papers (16 theses, 4 articles); VII - Dermeval Saviani, referred to in 16 papers (1 dissertation, 11 theses, 4 articles); VIII - L. Scheibe, with different works referred to in 10 papers ( 7 theses, 3 articles); IX - Carmem Silvia Bissoli da Silva, referred to in 12 studies (10 theses, 2 articles); X - Maurice Tardif, referred to in 10 theses; XI Helena Costa Lopes de Freitas, referred to in 5 papers (4 theses, 1 article); XII - Franco Cambi, referred to in 4 papers ( 3 theses, 1 article); and XIII - Paulo Freire, with several works referred to in 9 papers (8 theses, 1 dissertation).

It was verified that, when it comes to studies on the "pedagogy" category, there is a great number of works among those mapped that resort to the theoretical support of Selma Garrido Pimenta (16 papers), Iria Brzezinski (14 papers), José Carlos Libâneo (20 papers) e Dermeval Saviani (16 papers), to the detriment of others. It is worth also noting that Paulo Freire's works were used in a smaller scale; he was already referred to in the discussion about the "culture of silence" topic. For this category (Pedagogy), there are general and recurring discussions about the National Education Council/Full Council Resolution No. 1/2006, which established the National Curricular Guidelines of the Pedagogy Program, that, according to Brzezinski (2011), considers teaching the basis of the educator's professional identity, but leads to a multiple and complex identity characteristic of educators, in which being a teacher, being a researcher and being a manager are all interconnected.

Thus, the State of the Question contained herein reflects the author's own narrative, bringing, in the end of the bibliographical survey and the first (preliminary) analysis stage, the mapping of 36 papers, 10 of which are on the culture of silence, and 26 are about the educator's professional identity, found in the following repositories: I - CAPES Theses and Dissertations Catalog (14 papers); II - Digital Brazilian Library of Theses and Dissertations (8 papers); and III - CAPES Journals Platform (14 papers). These data confirm the existence of only a few productions about the culture of silence, which reveals the need of deeper studies in the area, especially in doctoral programs. When connected around the educator's identity, no study was mapped. Such absence contributed towards reaffirming the interest in the subject, the notoriety of the research, and the study's potential of contribution.

After the second stage of analysis, which was centered on the theoretical and methodological support, it is possible to conclude that the qualitative approach of the investigation becomes a priority in research in the education area, and, on other subjects, with an emphasis on bibliographic, documentary, and field research. We can also notice the recurrent use of bibliographic review, documentary review, questionnaire application, and conduction of semi-structured interviews as data collection strategies.

This analysis allowed us to understand that the theoretical and methodological assumptions of qualitative field research would be the best choice to increase the reach of the objectives proposed in the research (under development), with an emphasis on the theoretical framework supported on the studies by: I - Paulo Freire and Venício Artur Lima ("culture of silence" category); II - Stuart Hall and Claude Dubar ("identity" category); and III - Selma Garrido Pimenta, Iria Brzezinski, José Carlos Libâneo and Dermeval Saviani ("pedagogy” category). The definition of the categories, the possible theoretical chapters, as well as the route of the theoretical and methodological framework were also supported by the SQ carried out.

\section{Final remarks}

The State of the Question developed herein registered, from an initial bibliographic survey, the status of the investigative object in the current science scene. This process made it possible to build the specific object of the research expanded at the doctoral level, its objectives, the delimitation of the problem, and the analysis categories, and the choice of the main theoretical references in the area. It is known that there are several discussions and understandings around the definitions of the SQ. It is worth noting, however, that, in this study, such bibliographic survey was established within the parameters of interest to the author, resorting to significant 
documents and considering that the findings have to be "[...] necessarily or directly connected to the topic: they must refer to what specifically exists in publications or studies with relation to this, in the area of investigation of students/researchers, in their professions, whether at the local, national or international level" (NÓBREGATHERRIEN; THERRIEN, 2004, p. 10).

Research/study results were obtained about the problem investigated still being carried out, which reflects a specific literature review and made it possible to have a clearer delimitation of the object, to prepare the analysis categories, and to later interpret the data based on the theoretical framework chosen by the author. These frameworks express position, perceptions of science, sensitivity, creativity, dedication, competences as for the planning, written language and argumentation, as well as a contributing proposal to this field of knowledge.

Thus, in a coherent and organized manner, a bibliographic analysis framework was produced, as well as contributions made to clarify the topic under investigation, and to subsidize further and deeper research. In view of the findings, routes and conclusions of previous research, this SQ is a result of the author's own perception, argumentation and presentation.

In view of the study on the State of the Question analyzed above, we verify that such process requires scientific rigor, mastery of the concepts, of the literature, and of the structures and search tools of the various research bases, as well as it expresses a new way of directing the scientific process, understanding and advancing the scientific production process, of trying to characterize the object, categories, originality, and contribution. This differs from: I - the literature review, which is focused on the theoretical analysis of study support;II - the state of the art, which, due to its enumerating and descriptive nature, aims to discuss a specific academic production situated in a given field of knowledge; and III - the integrative review, which consists of a synthesis about a specific subject aiming its practical applicability.

Finally, it acknowledges the preliminary importance of the study about the State of the Question for the critical, creative, and contributing development of scientific research, thus evoking the pertinence of more investigations and productions about the SQ as an original, creative, critical and contributing way of understanding, both theoretically and methodologically, a research work.

\section{References}

Alves-Mazzoti, Alda Judith (1998). Bibliography review. In. Alves Mazzoti, Alda Judith, Gewandsznajder, Fernando (1998). The method in Natural and Social Sciences: quantitative and qualitative research. São Paulo: Pioneira, p. 179-188.

Bogdan, Robert; Biklen, Sari Knopp (2006). Qualitative research in Education. An introduction to theory and methods. Porto: Porto Editora.

Brzezinski, I (2011). Pedagogue: Outlining Identity (s). UFG Magazine / July, nº 10.

DUBAR, Claude (2005). Socialization: construction of social and professional identities. São Paulo: Martins Fontes.

Freire, Paulo (1996). Pedagogy of autonomy: knowledge necessary for educational practice. 25th ed. São Paulo: Paz e Terra.

Freire, Paulo (2019). Pedagogy of the oppressed. 17th ed. Rio de Janeiro: Peace and Earth.

Hall, S (2004). Cultural identity in postmodernity. 9 ed. Trad. Tomaz Tadeu da Silva and Guacira Lopes Louro. Rio de Janeiro: DP\&A.

Lima, Venício Artur de (2019). Beyond literacy: culture of silence and the 50 years of pedagogy of the oppressed.

Carta Maior,

2018. Available

at: https://www.cartamaior.com.br/?\%2FEditoria\%2FPolitica\%2FPara-alem-da-alfabetizacao-cultura-dosilencio-e-os-50-anos-da- pedagogy-of-the oppressed\% 2F4\% 2F40403. Accessed: 09/14/2019.

Lima, Venício Artur de (2011). From the culture of silence to the right to communication. Observatory of the press. Edition 669, Ano 19, $\mathrm{n}^{\circ}$ 1054. Available at: http://observatoriodaimprensa.com.br/feito-desfeitas/dacultura-do-silencio-ao-direito-a-comunicacao/. Accessed 08/10/2019.

Ludke, Menga; andré, Marli e. d. (1986). The Education research: qualitative approaches. São Paulo: EPU.

Nóbrega-Therrien, Sílvia Maria; Therrien, Jacques (2004). Scientific works and the state of the question: theoretical and methodological reflections. Studies in Educational Evaluation, São Paulo, Vol. 15, n.30, jul.dez., p.05-16.

Nóbrega-Therrien, Sílvia Maria; Therrien, Jacques (2010). The state of the matter: theoretical-methodological contributions and reports of its production in scientific works In: FARIAS, Isabel Maria Sabino de; NUNES, Joao Batista Carvalho; NOBREGA THERRIEN, Silvia Maria (Org.). Scientific research for beginners: walking in the maze. Fortaleza: EdUECE, p.33-51.

DANIELE CARIOLANO DA SILVA (Author): Student of the Doctorate in Education course by the Graduate Program in Education at the State University of Ceará - PPGE / UECE. Academic Master's in Education and Specialization in Children's Literacy from the State University of Ceará. Specialization in Teaching in Higher 
Education by the Integrated Faculty of Grande Fortaleza. Graduation in Pedagogy and Qualification in School Administration from UECE. She is currently a pedagogue at the Federal Institute of Education, Science and Technology of Ceará - IFCE / Campus Quixadá.

JACQUES TERRIEN (Author): Graduated in Pedagogy - Universidade Santa Úrsula, Rio de Janeiro (1972), Master in Philosophy - Université de Montréal, Canada (1964), Graduated in Pastoral Theology - Colégio Máximo Cristo Rei, Brazil (1969), Master in Education - Cornell University (1976), and doctorate in Education Cornell University, USA (1979). He has a postdoctoral degree at Université Laval, Canada (1992) and at Universitat de Valencia, Spain (2007). Senior Researcher at CNPq and Leader of the Educator's Knowledge and Social Practice Research Group. Retired full professor at the Federal University of Ceará (UFC) where he was Director of the Faculty of Education and Coordinator of the Graduate Program in Education. He is a research professor in the Graduate Program in Education at the State University of Ceará (UECE). He was Dean of Undergraduate Teaching at the University of International Integration of Afro-Brazilian Lusophony (UNILAB$\mathrm{CE}$ ). Participated in education committees at CNPq, CAPES, FUNCAP and INEP / MEC. His experience in the area of education predominates in the field of Teaching Knowledge, acting mainly on the following themes: pedagogy, teacher training, teaching work, epistemology of teaching practice, pedagogical rationality, learning, education in the field and educational policy. 